\title{
Book Review: Shadow's Law, The True Story of a Swedish Detective Inspector Fighting Prostitution by Simon Haggstrom
}

Melissa Farley

mfarley@prostitutionresearch.com

\section{Recommended Citation}

Farley, Melissa (2017) "Book Review: Shadow's Law, The True Story of a Swedish Detective Inspector Fighting Prostitution by Simon Haggstrom," Dignity: A Journal of Analysis of Exploitation and Violence: Vol. 2: Iss. 2, Article 5. https://doi.org/10.23860/dignity.2017.02.02.05

This Book Review is brought to you for free and open access by DigitalCommons@URI. It has been accepted for inclusion in Dignity: A Journal of Analysis of Exploitation and Violence by an authorized editor of DigitalCommons@URI. For more information, please contact digitalcommons-group@uri.edu. 


\section{Book Review: Shadow's Law, The True Story of a Swedish Detective Inspector}

Fighting Prostitution by Simon Haggstrom

\section{Keywords}

Sweden, prostitution, law, law enforcement

Creative Commons License

(c) (i) $(9)$

This work is licensed under a Creative Commons Attribution-Noncommercial-No Derivative Works 4.0 License. 
DIGNITY

Volume 2, Issue 2, Article 5, 2017
A JOURNAL ON

SEXUAL EXPLOITATION

AND VIOLENCE

\section{BOOK REVIEW: SHADOW'S LAW, THE TRUE STORY OF A SWEDISH DETECTIVE INSPECTOR FIGHTING PROSTITUTION BY SIMON HÄGGSTRÖM, BULLET POINT PUBLISHING, STOCKHOLM, 2016, 413 PAGES \\ Melissa Farley \\ Prostitution Research and Education}

\section{KEYWORDS}

Sweden, prostitution, law, law enforcement

$\mathrm{S}$ IMON HÄGGSTRÖM'S 2016 book, Shadow's Law, The True Story of a Swedish Detective Inspector Fighting Prostitution, is a gem. This book is a valuable resource for anyone who wants a close look at how the institution of prostitution operates, at who benefits and who is hurt. For abolitionists, it's a much-needed tool for confronting prostitution-harm-denial and for making the connections between prostitution, trafficking, and pornography.

Häggström has worked with the Stockholm police for 12 years. He is familiar with urban prostitution and trafficking, and with the application of the 1999 Swedish prostitution law which was aimed specifically at protecting the most vulnerable groups of people in the country. The law understands sex buyers as perpetrators of violence and women selling sex as victims of that violence. Häggström quotes a woman selling sex in Stockholm who explains, "People who've never had to fight to survive won't understand why we're standing on this street." He introduces us to a number of women prostituting in Stockholm, and in their stories, he provides powerful accounts of the forces driving women into prostitution - poverty, sexism, past abuse, addiction, prejudice against those who are ethnically marginalized.

It is challenging for abolitionists to avoid minimizing the deliberate cruelties of prostitution. Häggström struggles against his own denial of the predatory cruelty of prostitution. It is painful to witness and to know that the sex trade is very much a transaction of hunter and prey (Bounds, Delaney, \& Julion, 2017). Shadow's Law has some very helpful case studies of sex buyers. Häggström is a deeply curious person, and he works intently to understand why men buy sex. His observations and analysis of men's buying sex, based on years of experience, are invaluable for abolitionists who have not had an in-depth conversation with men who buy women for sexual use. Häggström makes it clear that sex buyers are not like other men, that their sexual satisfaction is more important to them than women's well-being, and that sex buyers' rationalizations for buying sex (which protect the men from hating themselves) form the basis for popular conceptions of prostitution: that it's a voluntary choice, that the women like prostitution, that they get to keep the money, that prostitution is like any other job. Debunking sex trade mythology 
about legal prostitution, Häggström notes that sex buyers are "rougher and nastier" when prostitution is legalized, when it is socially mainstreamed, and when acts previously considered high-risk or too violent are listed for sale and become acceptable. In addition to his experience policing in Stockholm, Häggström has investigated and studied other legal approaches to prostitution such as Germany's. He notes that the murder rate in German legal prostitution compares unfavorably with the nonexistent murder rate of women in Swedish prostitution during the same time period. His observations are in synchrony with organized crime experts who have reported on German legal prostitution (Paulus, 2013).

Observing interactions between sex buyers and women soliciting in the street, Häggström describes the "uncontrolled hatred" in sex buyers that emerges when they are rejected by prostituting women and when they realize that the women are repulsed by them. This results in sex buyers' violence against women in prostitution. A sex buyer quoted by Häggström wrote, "...Was like she didn't want to be touched and probably would have preferred fucking through a wall, both of us dressed in plastic suits."

Well...yes. This is at the heart of what Detective Inspector Häggström has learned in his years in the prostitution unit of the Stockholm police: the women don't want prostitution, they are only there because there are no other alternatives. His sensitivity to emotional trauma before and also during prostitution, suggests its critical importance in the effective policing of prostitution. And his compassion toward the women who he calls human beings rather than prostitutes is evident throughout this important book.

Today's prostitution-demand-reduction approaches to ending trafficking in the United States focus almost exclusively on arresting sex buyers while ignoring the other two elements of the Swedish law. The Swedish prostitution law does all three. Arresting johns without providing alternatives to prostitution such as housing, job training, and treatment for the harms of prostitution such as physical and mental health care - can make life more difficult for women in prostitution. To follow the Swedish model, it is necessary to not only arrest sex buyers but to also decriminalize women in prostitution and to provide them with urgently needed support to get out, heal, and stay out of prostitution. Although it is costly to provide these well-deserved services, on many levels, it costs us more not to provide them. The Swedish prostitution law, in addition to challenging sexism, also confronts racism and economic inequality. We have some things to learn from the Swedes about class. I'm writing this review on a day in May 2017 when some politicians in the United States have attempted to deny the basic human right of medical care to millions of its less privileged citizens. As former Swedish Minister of Gender Equality Margareta Winberg (2001) asked some years ago, "Shall we accept the fact that certain women and children, primarily girls, often those who are most economically and ethnically marginalized, are treated as a lower class, whose purpose is to serve men sexually?" Overwhelmingly, the Swedish public has said "no." Sadly, in the United States, there are many people who still think it is acceptable to deny certain classes of people the right to clean water, decent schools, healthcare, and alternatives to prostitution. Simon Häggström's book shows us the workings of a progressive antitrafficking law that not only focuses on the perpetrators of harm but extends restitution to those who have been harmed by prostitution. 


\section{AUTHOR BIOGRAPHY}

Melissa Farley is a psychologist who is Executive Director of Prostitution Research and Education, www.prostitutionresearch.com, a widely-used resource for scholars, policymakers, survivors of prostitution, and advocates. Farley has 49 publications in the field of violence against women, most of which address prostitution, pornography, and sex trafficking. Her work, with many coauthors, has been used by governments in South Africa, Canada, England, New Zealand, Ghana, United Kingdom, Cambodia, and United States for education and policy development. She co-authored the first international survey of prostitution and PTSD in nine countries (2003); the first psychological research on the lives of trafficked Native American women in the United States (2011); and the first study comparing sex buyers to non-sex buyers (2015). Email: mfarley@prostitutionresearch.com.

\section{RECOMMENDEDED CITATION}

Farley, Melissa. (2017). Book Review: Shadow's law: The true story of a Swedish detective fighting prostitution. Dignity: A Journal of Sexual Exploitation and Violence. Vol. 2, Issue 2, Article 5. doi:10.23860/dignity.2017.02.02.05. Available at http://digitalcommons.uri.edu/dignity/vol2/iss2/5.

\section{REFERENCES}

Bounds, D., Delaney, K.R., and Julion, W. (2017, March) Hunter-prey discourse: A critical discourse analysis of the online posts of men who buy sex. Journal of the American Psychiatric Nurses Association.

Paulus, M. (2013) Out of Control: On liberties and criminal developments in the redlight districts of the Federal Republic of Germany. Available at https://ressourcesprostitution.wordpress.com/2014/05/06/m-paulus-out-ofcontrol-on-liberties-and-criminal-developments-in-the-redlight-districts-of-thefederal-republic-of-germany/

Winberg, M. (2001) Remarks at International Conference Against Male Violence Against Women with a Focus on Prostitution and Trafficking. February 2-4, 2001, sponsored by National Organization for Battered Women's Shelters (ROKS), Stockholm. 